\title{
The impact of ownership structure on firm performance: static and dynamic panel data evidence from china's listed companies
}

\author{
Hong Shan ${ }^{1,2, a}$ and Guangming Gong ${ }^{1}$ \\ ${ }^{1}$ Business School, Hunan University, Changsha 410000, China \\ ${ }^{2}$ Hunan Technical College of Railway High-Speed, Hengyang 421000, China
}

\begin{abstract}
In this paper, we conduct static and dynamic panel data analysis of relationship between ownership structure and firm performance. The result suggests that the concentration of ownership plays an important role to firms. It is the concentration of ownership to the largest shareholder that can significantly improve the long-term firm performance, so the current changes of ownership concentration will obviously reduce performance. As time goes on, the negative effects gradually disappear and may even have a certain positive role on enterprise performance. Therefore, it is very important for the largest shareholder to highly hold shares for a long time and to attempt to maintain the ownership stable.
\end{abstract}

\section{Introduction}

Early neoclassical economists simply regard enterprise as "a black box" which means that enterprise performance must be output results of the corresponding input. However, the case that enterprises having the same quantifiable inputs have different output results exists in real life. Thus, the importance of enterprise ownership structure arrangement is mentioned repeatedly. The nature of enterprise is a bundle of ownership $[1,2]$, although the main part of performance is output result from input, the arrangement of ownership structure also affects the performance to a certain extent.

In fact, the ownership structure is a kind of important corporate governance mechanism, for listed companies the improper arrangement have a major impact on policies such as dividends, investment, personnel etc, will further affect the behavior of small and medium-sized investors. Although previous researches on ownership structure are comparatively mature. A conspicuous defect is that very few studies have controlled for firm heterogeneity or considered dynamic effects in the correlation between ownership structure and firm performance.

\section{Literature review}

Ownership structure can be depicted from the adscription, the distribution (concentrated or decentralized state) of ownership and the separation of the largest shareholders' ownership (cash-flow) rights and controlling (voting) rights, and scholars also discuss the effects of ownership structure from such several aspects in their analysis and tests. Among these, the ownership truly belongs to nation or private, is restricted by the social and political environment the enterprise is in; and control right of the largest shareholder is born with its ownership and is determined according to the shareholdings. Therefore, research is focused on the distribution, should ownership be centralized or decentralized, whether some leverage is needed from other shareholders.

Because highly decentralized ownership can eliminate the expropriation behavior of the largest shareholders to the interests of minority shareholders, it once was considered as a better ownership structure. However highly decentralized ownership also seriously generate agency conflicts between shareholders and managers, thus it is beneficial for the enterprise to concentrate the ownership to a certain extent. Demsetz, Shleifer and Vishny find that many listed companies exist controlling shareholders, and the phenomenon of ownership concentration is increasingly common [3, 4]. The ownership structure of Chinese listed companies is highly concentrated, and generally has controlling shareholder with large share $[5,6]$.

La Porta et al. find that there are widespread "Tunneling" behaviors in many countries, which would harm the interests of the company and have a negative impact on performance. Conversely, Shleifer and Vishny find that higher degree of ownership concentration makes the controlling shareholder has stronger motivation and ability to impact and monitor managers, thus the managers have smaller opportunism behavior tendency, which could improve enterprise performance [4]. Empirical results of $\mathrm{Xu}$ et al. present a significant positive linear relationship between the operating performance and ownership concentration [5]. However, Holderness and Sheehan, Mehran, and Demsetz and Villalonga have similar conclusion that there is no statistical significant correlation

a Corresponding author: rainbowshan71@qq.com 
between ownership structure and corporate performance [7, $8,3]$.

In the 1990s, corporate governance research find that except a single big shareholder control the company, multiple large shareholders together control the company is also a kind of common phenomenon, so concept of checks-and-balances is introduced into the field of the ownership research. Bennedsen and Wolfenzon consider that ownership structure that contains more than one major shareholder is an appropriate choice for the founders [9]. Bai et al and Xia and Zhang find that ownership checks-and-balances have a positive effect on the Chinese company value. However, $\mathrm{Xu}$ et al. find that high degree of ownership checks-and-balances have a negative impact to the company's operating performance [5].

Table 1. The impact of ownership structure on firm performance using static panel data analysis.

\begin{tabular}{|c|c|c|c|c|}
\hline \multirow{3}{*}{$\begin{array}{l}\text { Variable } \\
\text { Intercept }\end{array}$} & \multicolumn{4}{|c|}{ Dependent Variable: PE } \\
\hline & \multicolumn{2}{|c|}{$\mathbf{P E}=\mathbf{R O A}$} & \multicolumn{2}{|c|}{$\mathbf{P E}=\mathbf{R O E}$} \\
\hline & $-0.001(0.05)$ & $-0.001(0.05)$ & $-0.098(0.113)$ & $-0.097(0.112)$ \\
\hline private & $0.015^{* *}(0.007)$ & $0.015^{* *}(0.007)$ & $0.035^{* *}(0.016)$ & $0.035^{* *}(0.016)$ \\
\hline Sep & $0.003^{*}(0.001)$ & $0.003^{* *}(0.001)$ & $0.006^{*}(0.003)$ & $0.006^{*}(0.003)$ \\
\hline $\mathrm{PC}$ & $-0.0006^{* * *}(0.0002)$ & $-0.0006^{* * *}(0.0002)$ & $-0.001^{* * *}(0.0005)$ & $-0.001^{* * *}(0.0005)$ \\
\hline Lag PC & $0.0004^{* *}(0.0002)$ & $0.0005^{* *}(0.0002)$ & $0.001^{* *}(0.0005)$ & $0.001^{* * * *}(0.0005)$ \\
\hline $\mathrm{Z} 1$ & $-0.011^{* *}(0.005)$ & & $-0.034^{* * *}(0.012)$ & \\
\hline Lag Z1 & $0.013^{* *}(0.005)$ & & $0.034^{* * *}(0.012)$ & \\
\hline $\mathrm{Z2}$ & & $-0.009^{* *}(0.004)$ & & $-0.025^{* * *}(0.009)$ \\
\hline Lag Z2 & & $0.013^{* * *}(0.004)$ & & $0.031^{* * *}(0.009)$ \\
\hline Size & $0.066^{* * *}(0.004)$ & $0.066^{* * *}(0.004)$ & $0.14^{* * *}(0.01)$ & $0.14^{* * *}(0.01)$ \\
\hline Lag Size & $-0.061^{* * *}(0.004)$ & $-0.062^{* * *}(0.004)$ & $-0.132^{* * *}(0.01)$ & $-0.132^{* * *}(0.01)$ \\
\hline Lev & $-0.241^{* * *}(0.012)$ & $-0.241^{* * *}(0.012)$ & $-0.449^{* * *}(0.027)$ & $-0.451^{* * *}(0.027)$ \\
\hline Lag Lev & $0.118^{* * *}(0.012)$ & $0.12^{* * *}(0.012)$ & $0.377^{* * *}(0.027)$ & $0.381^{* * *}(0.027)$ \\
\hline Growth & $0.001^{* * *}(0.0003)$ & $0.001^{* * *}(0.0003)$ & $0.002^{* *}(0.0007)$ & $0.002^{* *}(0.0007)$ \\
\hline Lag Growth & $0.005^{* * *}(0.002)$ & $0.005^{* * *}(0.002)$ & $0.009^{* * *}(0.003)$ & $0.009^{* * *}(0.003)$ \\
\hline $\mathrm{F}$ & $4.62^{* * *}$ & $4.61^{* * *}$ & $2.69^{* * *}$ & $2.68^{* * *}$ \\
\hline Serial correlation & $8.723^{* * *}$ & $9.13^{* * *}$ & 0.051 & 0.041 \\
\hline Hausman & $497.69^{* * *}$ & $466.57^{* * *}$ & $198.97^{* * *}$ & $171.75^{* * *}$ \\
\hline $\mathrm{R}^{2}$ within & 0.233 & 0.235 & 0.182 & 0.183 \\
\hline Samples & \multicolumn{4}{|c|}{2304} \\
\hline
\end{tabular}

Notes: (i) Figures in parentheses are standard errors. (ii) Hausman is the Hausman test for fixed effects over random effects. (iii) Serial correlation is the test for first order serial correlation in fixed effects models. (iv) $* * * * *$ and $*$ are symbols of significance at $1 \%, 5 \%$ and $10 \%$ respectively (twotailed test).

\section{Study design}

Balanced panel data refer to two-dimension data at the same time, so it not only avoids the inherent problems of the cross section data regression, but also avoids comparability among different individuals using the unbalanced panel data. These advantages make balanced panel data analysis is a more feasible equation model than those used alone cross section or time series data, and is adopted in our research.

Combining with the above analysis and relevant empirical research results, the econometric model is set as follows.

$\mathrm{PE}_{\mathrm{i}, \mathrm{t}}=\beta_{0}+\beta_{1} \times$ Private $_{\mathrm{i}, \mathrm{t}}+\beta_{2} \times$ Sep $_{\mathrm{i}, \mathrm{t}} \quad+\beta_{3} \times \mathrm{PC}_{\mathrm{i}, \mathrm{t}}+\beta_{4} \times \mathrm{PC}_{\mathrm{i}, \mathrm{t}-\mathrm{1}}$ $+\beta_{5} \times \mathrm{PB}_{\mathrm{i}, \mathrm{t}}+\beta_{6} \times \mathrm{PB}_{\mathrm{i}, \mathrm{t}-1}+\beta_{\mathrm{C}} \times$ Controlvariables $_{\mathrm{i}, \mathrm{t}}+\beta_{\mathrm{L}} \times$ Controlva riables $_{\mathrm{i}, \mathrm{t}-1}+\varepsilon$
In formula (1), variable $\mathrm{PE}$ stands for corporate performance, Private for adscription of ownership, Sep for separation of two rights, PC for ownership concentration, and $\mathrm{PB}$ for ownership checks-and-balances.

In addition, we also test for dynamic effects. One simple way of allowing for dynamic effects in panel data models is by the inclusion of a lagged dependent variable and this is a common approach in studies of firm performance. The empirical model is as follows.

$\mathrm{PE}_{\mathrm{i}, \mathrm{t}}=\beta_{0} \times \mathrm{PE}_{\mathrm{i}, \mathrm{t}-1}+\beta_{1} \times$ Private $_{\mathrm{i}, \mathrm{t}}+\beta_{2} \times$ Sep $_{\mathrm{i}, \mathrm{t}}+\beta_{3} \times \mathrm{PC}_{\mathrm{i}, \mathrm{t}}+\beta_{4} \times \mathrm{PC}_{\mathrm{i}, \mathrm{t}-1}$ $+\beta_{5} \times \mathrm{PB}_{\mathrm{i}, \mathrm{t}}+\beta_{6} \times \mathrm{PB}_{\mathrm{i}, \mathrm{t}-1}+\beta_{\mathrm{C}} \times$ Controlvariables $_{\mathrm{i}, \mathrm{t}}+\beta_{\mathrm{L}} \times$ Controlva riables $_{\mathrm{i}, \mathrm{t}-1}+\varepsilon$

\section{Sample and measurement of variables}

\subsection{Data collecting and processing}


The sample is based on 288 Chinese A-share listed firms in Shenzhen and Shanghai securities exchanges between 2003 and 2011. In the process of data collection and sorting, the financial listed companies are taken out from the sample. Then the ST companies and list companies with missing data on some variables are eliminated. This leaves us with a balanced panel data set of 288 firms. All financial data are obtained from CSMAR database (1).

\subsection{Variable definition}

Firm performance is our dependent variable. It is the general point that Tobin's Q can show the information about future earnings cash flow and capital opportunity cost. But the high volatility and turnover rate of the secondary market make the Tobin's Q difficult to reflect the enterprise's performance $[10,11]$. For this reason, we consider two alternative measures of performance, return on assets and return on equity.

This paper adopts the shareholding ratio of the largest shareholder, usually is the controlling shareholder, to measure ownership concentration, using PC as a variable symbol. Except the largest shareholder, other shareholders' checks-and-balances effect is quantified as: The ratio of 2 to 5 large shareholders' total shareholdings to the largest shareholder's shareholding, using z1 as a variable symbol; The ratio between 2 to 10 large shareholders' total shareholdings and the largest shareholder's shareholding, with $\mathrm{z} 2$ as a variable symbol(2).

In Chinese public companies, the ultimate controller generally enhances his control through pyramid structures and cross-holdings among firms, thus generate separation of ownership and control. Refer to the calculation of Claessens et al, we also use the ratio between the voting rights and the cash-flow rights to measure the separation of ownership and control of the controlling shareholder, using Sep as a variable symbol $[12,13]$.

Lastly, we include some control variables to control for other potential influences on ownership structure and enterprise performance. Control variables that have been used in the literatures include firm size, capital structure and growth opportunity.

\section{Empirical results}

Our regression results are presented in Table 1 and table 2. In Table 1, we present the static panel data estimates of our models (1). The coefficient on Private is significantly positive, namely the performance of non-state-controlled listed companies is significantly higher than that of state-owned company. Separation of ownership and control is also conducive to the performance. For the ownership concentration and checks-and-balances variable,

(1)CSMAR Database include all financial data and marketing data of China capital market since 1990, which was developed according to the international standards of database to meet the requirement of academic research.

(2)Due to the limitation of the data, not all associated shareholders shareholding ratio were combined as one shareholder. the coefficient on current and lagged are all significantly different to zero, and the signs are the same. Both ownership concentration and checks-and-balances in the current period is negatively related to the enterprise performance, the calculated results are far different with the traditional view point. The lagged coefficient also have the same confusion. Thus, the static models can't prove that ownership should be more concentrated on the controlling shareholder or more balanced distribute among large shareholders $[14,15]$. We conduct a test for serial correlation in the residuals of this model.

The test result suggests evidence of serial correlation when using ROA as performance variable. One possible source of this problem is the existence of dynamic effects.

In Table 2, we present dynamic panel data estimates using the Arellano and Bond estimator. Only the coefficient of ownership concentration is statistical significant. In the long run, only the largest shareholder's stake would affect corporate performance. As time goes on, the impact of other characteristics of ownership on corporate performance is not so important. A powerful interpretation may be that these characteristics are attached to the current and lagged impact of the ownership concentrated to the largest shareholder on the enterprise is different. So we can assume that any shareholding changes of the largest shareholder will bring shocks to enterprises, and even negative effect, but after a period, bad effect disappear, positive effect generate. To test this hypothesis, our basic model assumes the form: $\mathrm{PE}_{\mathrm{i}, \mathrm{t}}=\beta_{0}+\beta_{1} \times$ Private $_{\mathrm{i}, \mathrm{t}}+\beta_{2} \times$ Sep $_{\mathrm{i}, \mathrm{t}}+\beta_{3} \times\left|\quad \Delta \quad \mathrm{PC}_{\mathrm{i}, \mathrm{t}}\right|+\beta_{4} \times \mid \Delta$

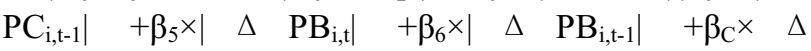
Controlvariables $_{\mathrm{i}, \mathrm{t}}+\beta_{\mathrm{L}} \times \Delta$ Controlvariables $_{\mathrm{i}, \mathrm{t}-1}+\varepsilon$ Where $\Delta$ var, variable in first differences; $\Delta$ var $_{\mathrm{t}-1}$, lagged differences; $\mid \Delta$ var $\mid$, absolute value of the differences. The fixed effect regression results are listed in table 5. Only the current coefficient of $|\triangle \mathrm{PC}|$ is significantly negative, indicates that changes of checks-and-balances of other big shareholders do not influence the enterprise. It is the largest shareholder's stake that really has a profound effect on corporate performance, so any changes, whether increase or decrease the shareholding, will cause shock to the enterprise at once, reduce the enterprise performance. The greater the shareholding change, the more negative impact to performance.

As time goes on, the negative effect would weaken even disappear. The results confirm the hypothesis mentioned above extremely well, and further illustrate the validity of the coefficient estimates in Table 2.

\section{Summary and concluding remark}

Our research results show that the largest shareholder's shareholding has a great influence to the enterprise, the higher stake could have a significant positive role to the enterprise in the future, so any change in the largest shareholder's shareholding will bring shocks in the current period, thus has a significant negative effect to the enterprise. 
Table 2. The impact of ownership structure on firm performance using dynamic panel data analysis (Arellano and Bond estimation).

\begin{tabular}{|c|c|c|c|c|}
\hline \multirow{3}{*}{$\begin{array}{l}\text { Variable } \\
\text { Lag PE }\end{array}$} & \multicolumn{4}{|c|}{ Dependent Variable: PE } \\
\hline & \multicolumn{2}{|c|}{$\mathrm{PE}=\mathrm{ROA}$} & \multicolumn{2}{|c|}{$\mathrm{PE}=\mathrm{ROE}$} \\
\hline & $-0.044(0.172)$ & $-0.047(0.172)$ & $-0.178(0.164)$ & $-0.169(0.167)$ \\
\hline Private & $-0.125(0.115)$ & $-0.142(0.129)$ & $-0.359(0.278)$ & $-0.405(0.311)$ \\
\hline Sep & $0.017(0.013)$ & $0.018(0.014)$ & $0.018(0.032)$ & $0.02(0.034)$ \\
\hline $\mathrm{PC}$ & $-0.002^{* *}(0.0008)$ & $-0.002^{* *}(0.0008)$ & $-0.003(0.002)$ & $-0.003(0.002)$ \\
\hline Lag PC & $0.002^{* * *}(0.0009)$ & $0.003^{* * *}(0.0008)$ & $0.004^{* *}(0.002)$ & $0.004^{* *}(0.002)$ \\
\hline $\mathrm{Z1}$ & $-0.029(0.045)$ & & $-0.059(0.111)$ & \\
\hline Lag Z1 & $0.048(0.047)$ & & $0.112(0.114)$ & \\
\hline $\mathrm{Z} 2$ & & $-0.016(0.034)$ & & $-0.022(0.084)$ \\
\hline Lag Z2 & & $0.043(0.034)$ & & $0.087(0.085)$ \\
\hline Size & $0.165^{* * *}(0.027)$ & $0.166^{* * *}(0.026)$ & $0.376^{* * *}(0.066)$ & $0.373^{* * *}(0.064)$ \\
\hline Lag Size & $-0.134^{* * *}(0.026)$ & $-0.133^{* * *}(0.026)$ & $-0.299^{* * *}(0.065)$ & $-0.295^{* * *}(0.063)$ \\
\hline Lev & $-0.329^{* * *}(0.093)$ & $-0.316^{* * *}(0.089)$ & $-0.894^{* * *}(0.225)$ & $-0.852^{* * *}(0.216)$ \\
\hline Lag Lev & $0.132(0.082)$ & $0.13(0.08)$ & $0.398^{* *}(0.198)$ & $0.394^{* *}(0.191)$ \\
\hline Growth & $0.003(0.003)$ & $0.003(0.003)$ & $0.01^{*}(0.006)$ & $0.011^{*}(0.006)$ \\
\hline Lag Growth & $0.003(0.003)$ & $0.003(0.003)$ & $0.005(0.007)$ & $0.005(0.007)$ \\
\hline $\mathrm{AR}(1)$ & $-3.75^{* * *}$ & $-3.72^{* * *}$ & $-3.69^{* * *}$ & $-3.56^{* * *}$ \\
\hline $\mathrm{AR}(2)$ & 0.73 & 0.67 & 1.11 & 1.06 \\
\hline Sargan & 18.74 & 20.35 & 16.54 & 17.77 \\
\hline Samples & & & & \\
\hline
\end{tabular}

Notes: (i) Figures in parentheses are standard errors. (ii) AR (1) and AR (2) are test for first and second order autocorrelation in the differenced residuals. (iii) Sargan is the Sargan tests of over-identifying restrictions. (iv) $* * *, * *$ and $*$ are symbols of significance at $1 \%, 5 \%$ and $10 \%$ respectively (two-tailed test).

Table 3. Ownership changes and firm performance.

\begin{tabular}{|c|c|c|c|c|}
\hline \multirow{3}{*}{$\begin{array}{l}\text { Variable } \\
\text { Intercept }\end{array}$} & \multicolumn{4}{|c|}{ Dependent Variable: PE } \\
\hline & \multicolumn{2}{|c|}{$\mathbf{P E}=\mathbf{R O A}$} & \multicolumn{2}{|c|}{$\mathbf{P E}=\mathbf{R O E}$} \\
\hline & $0.026^{* * *}(0.004)$ & $0.026^{* * *}(0.004)$ & $0.04^{* * *}(0.008)$ & $0.04^{* * *}(0.008)$ \\
\hline private & $0.015^{*}(0.009)$ & $0.015^{*}(0.009)$ & $0.037^{*}(0.02)$ & $0.037^{*}(0.02)$ \\
\hline Sep & $0.003^{*}(0.002)$ & $0.003^{*}(0.002)$ & $0.007^{*}(0.004)$ & $0.007^{*}(0.004)$ \\
\hline$|\Delta \mathrm{PC}|$ & $-0.0006^{* * *}(0.0002)$ & $-0.0005^{* * *}(0.0002)$ & $-0.002^{* * *}(0.0005)$ & $-0.0015^{* * *}(0.0005)$ \\
\hline $\mid \Delta \mathrm{PC}$ lag $\mid$ & $-0.0003(0.0002)$ & $-0.0003(0.0002)$ & $-0.0006(0.0005)$ & $-0.0006(0.0005)$ \\
\hline$|\Delta \mathrm{Z} 1|$ & $0.0009(0.006)$ & & $0.013(0.014)$ & \\
\hline$|\Delta \mathrm{Z} 1 \mathrm{lag}|$ & $0.008(0.006)$ & & $0.016(0.014)$ & \\
\hline$|\Delta \mathrm{Z} 2|$ & & $-0.002(0.005)$ & & $0.0007(0.01)$ \\
\hline$|\Delta \mathrm{Z} 2 \mathrm{lag}|$ & & $0.009^{*}(0.005)$ & & $0.016(0.011)$ \\
\hline Control variable & \multicolumn{4}{|c|}{ Controlled } \\
\hline $\mathrm{F}$ & $5.54^{* * *}$ & $5.54^{* * *}$ & $2.68^{* * *}$ & $2.67^{* * *}$ \\
\hline Hausman & $196.05^{* * *}$ & $237.51^{* * *}$ & $195.36^{* * *}$ & $205.27^{* * *}$ \\
\hline $\mathrm{R}^{2}$ within & 0.207 & 0.208 & 0.189 & 0.189 \\
\hline Samples & \multicolumn{4}{|c|}{2016} \\
\hline
\end{tabular}


In short, for the largest shareholder, it would generate the interest motivation of improving the corporate governance when holding stocks for a long time and with higher proportion, so as to generate incremental revenue and improve the enterprise performance. Every change of the largest shareholder's shareholding is a redistribution process of interest structure, thus will produce certain instability and a very adverse impact to the enterprise. Therefore, it is very important for enterprises to highly concentrate the ownership to the controlling shareholder for a long time and attempt to keep the ownership structure stable.

\section{References}

1. G. Gong, H. Shan, 2012, Collected Essays on Finance Economics, 5 (2012).

2. Z.L. Liu, Journal of Applied Sciences, 13, 21 (2013).

3. H. Demsetz, B. Villalonga, Journal of Corporate Finance, 7 (2001).

4. A. Shleifer, R. Vishny, Journal of Political Economy, 95 (1986).

5. L. Xu, Y. Xin, G. Chen, Economic Research Journal,
1 (2006).

6. Y.B. Zhu, J.S. Li, Journal of Mechanical Engineering Research and Developments 39, 2 (2016).

7. C.G. Holderness, D.P. Sheehan, Journal of Financial Economics, 20 (1988).

8. H. Mehran, Journal of Financial Economics, 38 (1995).

9. M. Bennedsen, D. Wolfenzon, Journal of Financial economics, 58, (2000).

10. G. Chen, M. Firth, L. Xu, 2009, Journal of Banking \& Finance, 33 (2009).

11. Q.L. Du, W.S. Tang, Journal of Mechanical Engineering Research and Developments 39, 1 (2016).

12. S. Claessens, S. Djankov, P.H. Joseph, Journal of Finance, 57 (2002).

13. S. Claessens, S. Djankov, L. Lang, Journal of Financial Economics, 58, 1 (2000).

14. F. Mara, L.H.P. Lang, Journal of Financial Economics, 65, 3 (2002).

15. L.R. Porta, F. Lopez-de-Silanes, A. Shleifer, R. Vishny, Journal of Financial Economics, 58 (2000). 